\title{
The Spillover Effects of U.S. Monetary Policy on Emerging Market Economies: Breaks, Asymmetries and Fundamentals
}

\author{
Geun-Young Kim*, Hail Park**, Peter Tillmann***
}

The views expressed herein are those of the authors and do not necessarily reflect the official views of the Bank of Korea. When reporting or citing this paper, the authors' names should always be explicitly stated.

* Economic Research Institute, Bank of Korea, E-mail: kgy3104@bok.or.kr.

** Department of International Business and Trade, Kyung Hee University, E-mail: hailpark@khu.ac.kr.

*** Department of Business and Economic Studies, Giessen University,

E-mail: peter.tillmann@wirtschaft.uni-giessen.de.

We thank Woon Gyu Choi, Soyoung Kim and Jin-Su Park for their helpful comments. 


\section{Contents}

1. Introduction

2. A VAR-X Model of Monetary Spillovers ……………...... 3

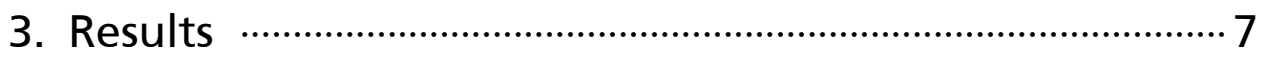

4. The Role of Macroeconomic Fundamentals ……….....20

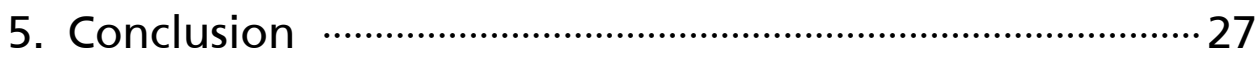

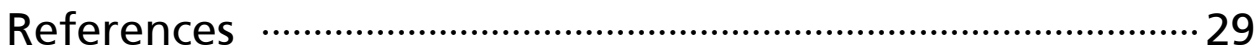

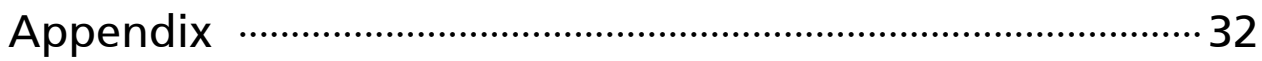




\section{The Spillover Effects of U.S. Monetary Policy on Emerging Market Economies: Breaks, Asymmetries and Fundamentals}

The recent implementation of unconventional monetary policies in advanced economies and the preparations for an eventual return to normalization have renewed the interest in spillover effects of monetary policy on emerging market economies. This paper estimates a series of VAR-X models for a set of 10 emerging economies, that is, VARs in which U.S. policy enters exogenously. The contribution of this paper is (1) to use an identified shock component of the U.S. (shadow) Federal Funds rate as a consistent policy instrument for conventional and unconventional policies, (2) to account for changes in the transmission of U.S. monetary policy over time, (3) to quantify asymmetries in the transmission of tightening and easing shocks, and (4) to relate the exposure of emerging countries with macroeconomic fundamentals. The results point to substantially nonlinear and asymmetric spillover effects, which pose challenges to policymakers.

Keywords: Conventional-Unconventional monetary policy, Spillovers, Emerging markets, VAR-X model, Asymmetries

JEL classification: E58, F32, F42 


\section{Introduction}

Monetary policy responses to the global financial crisis can shed light on the spillover effects of monetary policy to emerging economies. When the Federal Reserve ("Fed") adopted a series of unconventional monetary policies known as Quantitative Easing ("QE") and Forward Guidance in 2008, the side effects were transmitted through global financial markets. In particular, emerging economies felt the surge in liquidity after the adoption of $\mathrm{QE}$.

In 2014, the Fed has eventually unwound its asset purchases ("tapering") after announcing the tapering in 2013 and is expected to "lift-off" the Federal Funds rate gradually, that is, the Fed is about to normalize its monetary policy.

Spillover effects pose major challenges to policymakers in emerging countries (Lavigne et al., 2014: Chen et al., 2014: Tillmann, 2015: Chen et al., 2015: MacDonald, 2015). The flood of liquidity under $\mathrm{QE}$ is believed to lead to an easing of monetary conditions, a surge in asset prices and domestic currency appreciations. Furthermore, abundant liquidity is raising financial stability concerns. Many central banks and regulators have responded to this by a monetary tightening and/or the use of macroprudential policy tools. The reversal of capital flows after 2014 has led to a sharp depreciation and a drop in asset prices in emerging market economies. In order to choose the right policy response, understanding the nature of these spillovers is essential.

This paper presents a large collection of findings on the nature of spillover effects. We empirically quantify the recent spillover effects and make four contributions. First, we focus on the effects of both conventional and unconventional monetary policy. This is accomplished by using the identified shock component of the (shadow) Federal Funds rate as a measure of U.S. monetary policy, which allows us to estimate a consistent model under both policy regimes. Second, we study the notion of a "New Normal," i.e. a change in the pattern of spillovers after the financial crisis by comparing a pre-crisis and a post-crisis regime. Third, we allow for tightening and easing measures to have different effects. This enables us to quantify the asymmetric nature of the spillover effects. Fourth, we relate the strength of the spillover effects to the macroeconomic 
fundamentals of emerging market economies. As a result, we can identify which particular form of weakness gives rise to a large exposure to U.S. policy shocks.

Our main empirical tool for the analysis of policy transmission is a vector autoregression (VAR) model of standard financial variables of emerging markets, which we augment by introducing an exogenous change in U.S. monetary policy. The fact that U.S. policy enters exogenously transforms the model into a VAR-X model. In order to focus on unexpected changes in U.S. monetary conditions, we estimate an auxiliary VAR model for the U.S. economy and feed the identified policy shock into the VAR-X model for emerging market economies. From the perspective of a prototypical emerging economy, U.S. monetary policy can clearly be considered exogenous. Rather than estimating a panel model for a large set of emerging market economies, this paper estimates a series of country-specific time-series VAR-X models. We think this approach is better able to shed light on the large degree of heterogeneity across countries.

We find that spillovers are divergent. Both the sign and the size of spillovers changed over regime. We do not find, however, that spillovers are systematically higher post-2008. There are not only structural breaks over time but also asymmetries as regards the sign of the policy shock itself. In many countries, the spillovers after a tightening shock and an easing shock in the U.S. differ in terms of their absolute magnitude and their dynamics. From them, fundamentally weak economies appear to suffer from stronger spillovers than fundamentally strong economies.

The results are relevant for policymakers in emerging economies: our findings suggest that not all spillovers are equal. To the extent spillovers are asymmetric, the appropriate policy response cannot be linear. For example, if macroprudential policies are considered to offset the consequences of unwarranted spillover effects, these instruments have to be adjusted to be an efficient tool to contain the effects of U.S. policy shocks. In light of our results, the need to fine-tune macroprudential policies challenges the efficient design of appropriate policies. The interest rate lift-off and the subsequent return to an interest rate policy is likely to lead to renewed tensions in emerging market economies - which will put policies to a test. Our results show that strong macroeconomic fundamentals are the best way to make emerging economies less vulnerable to spillovers. 
This paper proceeds as follow. Section 2 introduces the VAR-X model, which is our main modeling framework. The main results are presented in Section 3. Section 4 related spillover effects to macroeconomic fundamentals. Sections 5 offers a concluding summary and draws policy implications.

\section{A VAR-X Model of Monetary Spillovers}

To estimate the spillover effects of U.S. monetary policy on emerging economies, we estimate a series of VAR-X models, i.e., VAR models augmented by an exogenous variable. Shocks to the exogenous variable are the focus of our study. VAR-X models have recently been used in the literature: Bassett et al. (2010) feed an exogenous credit supply shock in an otherwise standard VAR model of the U.S. economy to study the effects of an exogenous change in lending. Wu and Cavallo (2012) include an exogenous oil price shock in a VAR system. In a paper similar in focus to ours, Miyajima, Mohanty and Yetman (2014) estimate a panel VAR model of Asian economies where monetary policy in the U.S. enters as an exogenous variable. Compared to their paper we offer a unifying perspective on conventional and unconventional monetary policy and also allow for shifts in the strength of policy transmission over time. We also prefer a country-by-country perspective over a panel in order to link the strength of the transmission to economic fundamentals.

In our model, the vector of the first differences of $n$ endogenous variables, $Y_{t}$, is determined as follows

$$
Y_{t}=A_{0}+A(L) Y_{t}+b \times \Delta R_{t}^{U S}+\varepsilon_{t},
$$

where $A(L)$ is a polynomial in the lag operator. A measure of U.S. monetary policy is included as an exogenous variable, $\Delta R_{t}^{U S}$. The impact effect of U.S. policy on the endogenous variables is reflected by the vector $b .{ }^{1}$ )

1) Including lags of the exogenous variables does not change our findings. 
Since the stance of U.S. policy is clearly exogenous from the perspective of an emerging market economy, and we are interested in the endogenous responses to exogenous policy only, there is no need for further identifying assumptions. Hence, we do not intend to identify other shocks to the endogenous variables which would necessitate imposing identifying assumptions. The literature offers a range of identification schemes, all of which necessitate imposing more or less ad-hoc constraints. We take the VAR-X model as a useful representation of the dynamics of the data and thus avoid the arbitrariness involved in many identification schemes used in the literature.

The model is estimated on weekly data to avoid washing out the volatility in emerging markets when using monthly or even quarterly data. This is considered an important advantage in order to grasp the fast transmission of policy shocks to emerging economies. The vector of endogenous variables consists of (1) the log-difference of the nominal domestic stock price index, $\Delta s t o c k p_{t}$, (2) the log-difference of the nominal exchange rate against the U.S. dollar with an increase of the exchange rate reflecting a depreciation of the domestic currency, $\Delta e_{t}$, and (3) the change in domestic long-term bond yields, $\Delta i_{t}$,

$$
Y_{t}=\left(\Delta s t o c k p_{t}, \Delta e_{t}, \Delta i_{t}\right)^{\prime}
$$

The 10 countries included in this paper are Brazil (BRA), Chile (CHL), Czech Republic (CZR), Hungary (HUN), Indonesia (IND), Korea (KOR), Malaysia (MAL), Mexico (MEX), Philippines (PHL), and Poland (POL). The choice of countries is determined by the availability of weekly financial data and the desire to cover all major emerging regions of the world economy. Moreover, we include rather heterogeneous countries in terms of macroeconomic fundamentals or weaknesses - a fact that will be discusses below. We include six lags of the endogenous variables.

A crucial variable is our choice of $R_{t}^{U S}$. Our primary measure of U.S. monetary policy is the series of the U.S. (shadow) federal funds rate, provided by $\mathrm{Wu}$ and Xia (2014), which is derived from an estimated term structure model.2) A clear

2) The data is available under http://faculty.chicagobooth.edu/jing.wu/research/data/WX.html. An alternative is be the shadow rate estimated by Krippner (2014) which we also present estimation results in appendix. 
advantage of this measure of policy is that we can use a single indicator for both the period before the ZLB became binding and after. We thus do not change the policy instrument in our regression once the Fed adopted unconventional monetary policy tools. To estimate the impact of Fed policy, we derive the shock component of this (shadow) Federal Funds rate from an estimated VAR for the U.S. economy, to control for the changes of policy action owing to macroeconomic condition. Using the (shadow) Federal Fund rate as such as a measure of U.S. policy, which is what we do in the robustness section, is our secondary choice. A disadvantage of using exogenous (from the perspective of the emerging economy) changes in the shadow Federal Funds rate itself is that we do not distinguish between expected and unexpected interest rate changes. In fact, many of the tightening and easing steps implemented by the Fed were anticipated and communicated in advance. Hence, changes in the (shadow) Federal Fund rate, without further identifying assumptions, are not equal to unexpected shocks.

The shock component is derived from an auxiliary VAR model which we estimate for the U.S. based on monthly data. The auxiliary VAR includes real economic activity measured by the change in industrial production and the change in the CPI as well as the change in the Wu-Xia shadow rate. We include six lags of the endogenous variables. The model is estimated for the full sample, i.e. sample I plus sample II. In order to identify monetary policy shocks in this model, we impose restrictions on the signs of the impulse responses (Uhlig, 2005), an approach which is by now the standard in the monetary policy literature. Our restrictions imply that a monetary policy shock increases the (shadow) interest rate and depresses both the growth rate of industrial production and the change in consumer prices. These constraints are imposed for two months following the shock. ${ }^{3)}$ We find that a restrictive monetary policy shock leads to a persistent fall in growth rates of real activity and inflation. A historical decomposition allows us to decompose each endogenous variable into the fraction explained by the tightening shock and the remaining, not-identified driving forces. For the remainder of this paper we use the shock component of the change in the shadow

3) We do not provide the results of the auxiliary VAR model here. However, all outcomes are available upon request. 
rate, i.e. the change in monetary conditions coming as a surprise, as an exogenous regressor in our VAR-X model, i.e.

$$
Y_{t}=A_{0}+A(L) Y_{t}+b \times \Delta R_{t}^{s h o c k, U S}+\varepsilon_{t},
$$

where $\Delta R_{t}^{\text {shock, US }}$ is the shock component of the (shadow) Federal Funds rate obtained from adopting sign restrictions and a historical decomposition, respectively. This series is then interpolated from monthly to weekly frequency using EViews.4)

As mentioned before, we also use the change in the shadow Federal Funds rate itself as a measure of U.S. monetary policy, i.e.

$$
Y_{t}=A_{0}+A(L) Y_{t}+b \times \Delta R_{t}^{\text {shadow }, U S}+\varepsilon_{t},
$$

where $\Delta R_{t}^{\text {shadow, US }}$ is the first difference of the (shadow) Federal Funds rate.

Figure (1) presents our alternative measures of monetary policy which we feed into the emerging market VARs. We plot the identified shock component of the Wu and Xia (2014) shadow rate (in red) obtained from the auxiliary VAR system against the first difference of the shadow rate itself. The shock component, which is the unexpected part of the change in monetary conditions, commoves with the shadow rate. While in some cases the shock component explains the entire change of the shadow rate, e.g. in the second half of 2014, it is not explaining much of the shadow rate movement during the great financial crisis. ${ }^{5)}$ The reason is that in 2008/09 much of the Fed's action was in line with the Fed's reaction function and, hence, did not come as a surprise.

4) We believe interpolating the shadow rate to weekly frequency is an innocuous transformation. It is unlikely that we impose much additional on the data that would ultimately disturb our estimates.

5) See Francis et al. (2014) for an analysis of whether the shadow rate is a useful proxy for modeling policy in VAR models. 
Figure 1: U.S. Monetary Policy Shock Identified from an Auxiliary VAR Model for the U.S. in Comparison with Wu \& Xia (2014) Shadow Federal Funds Rate Change.

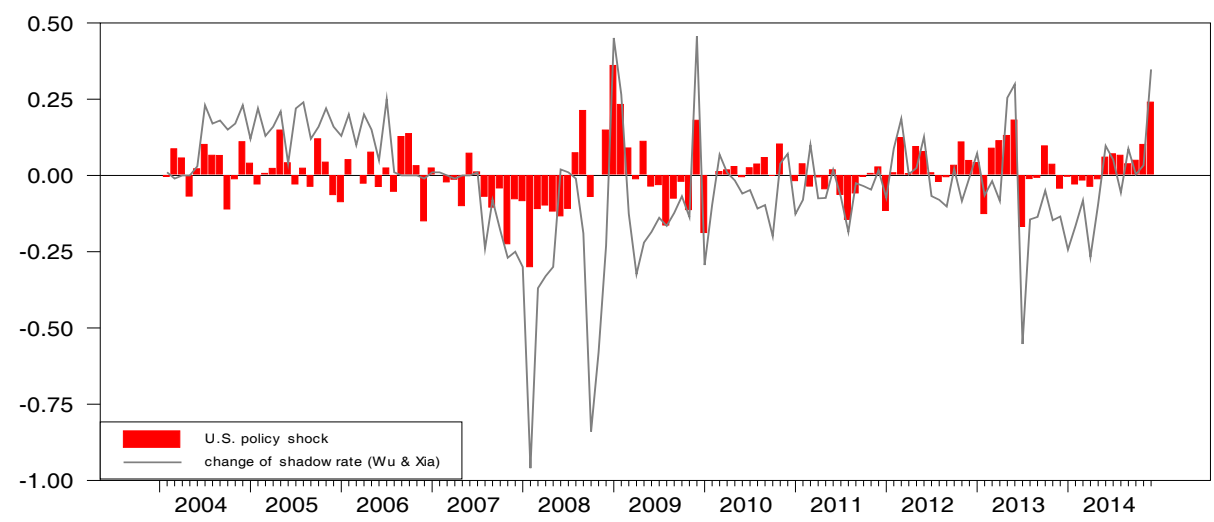

Note: The U.S. policy shock is identified in a estimated VAR model with the shadow Federal Funds rate and macroeconomic variables.

The model is estimated for two periods: The first sample (sample I) covers the period before the global financial crisis and extends over Jan.03.2004 Aug.30.2008, hence it ends before the collapse of Lehman Brothers.6) The second sample (sample II) begins on Nov.08.2008 and ends on Dec.27.2014. We deliberately exclude the September and October 2008 in order to prevent the exceptional volatility due to the peak of the crisis from affecting our estimates of policy spillovers. Roughly speaking, the sample I is characterized by conventional monetary policy, while the sample II is the period of unconventional monetary policies.

\section{Results}

We expect a tightening in the U.S., i.e. an increase in the shock component of the (shadow) Federal Funds rate, to lead to capital outflows from emerging

6) For some countries the estimation starts later due to data availability. 
economies. This would be consistent with a drop in domestic stock prices, a depreciation of the exchange rate and an increase in long-term bond yields of emerging economies. We will now discuss the results of our empirical analysis in light of these priors.

\subsection{Benchmark results}

The benchmark results are presented in Figure 2. All of these figures show the responses to an increase in the shock component of the Federal Funds rate of 25 basis points (bp) in the two alternative sample periods. We scale the results to a 25 bp increase because this is the size of the initial lift-off from the zero lower bound. The confidence bands reflect the 16 th and the 84 th percentiles of the distribution of draws.

Our main findings are threefold: First, not all responses are consistent with our prior discussed before. Take Korea as an example, see Figure (2f). In sample II we indeed see a fall in stock prices and a nominal depreciation. However, we find almost unchanged bond yields. In sample I, however, the signs of the responses are less consistent with our predictions. In fact, in sample I, a U.S. policy shock leads to an increase in stock prices and an appreciation of the KRW. This can also be observed for many other sample countries. Overall, we find that there is not one unanimous pattern of spillovers. In fact, spillovers are highly country-specific and also regime-dependent. This leads us to the second observation: For many sample countries the signs of the responses change across regimes, especially in stock and bond markets. FX markets respond into the same direction in both sample periods. Take Korea again: Before 2008, a tightening in the U.S. led to an increase in stock prices. ${ }^{7)}$ After 2008, however, the same tightening is associated with a fall in stock prices. Similar patterns with significant drops in stock prices during sample II are found in the Czech Republic, Mexico and Poland. What explains these opposite responses? One channel of transmission has been sketched before. According to this view, a tightening in the U.S. leads investors to

7) Chen et al. (2014) also highlight the fact that the intensity and the sign of spillovers change over time. 
Figure 2: Responses for EMEs to a Positive Monetary Policy Shock of 0.25 Percentage Points in the Post-2008 Sample: Benchmark Results

a. Brazil
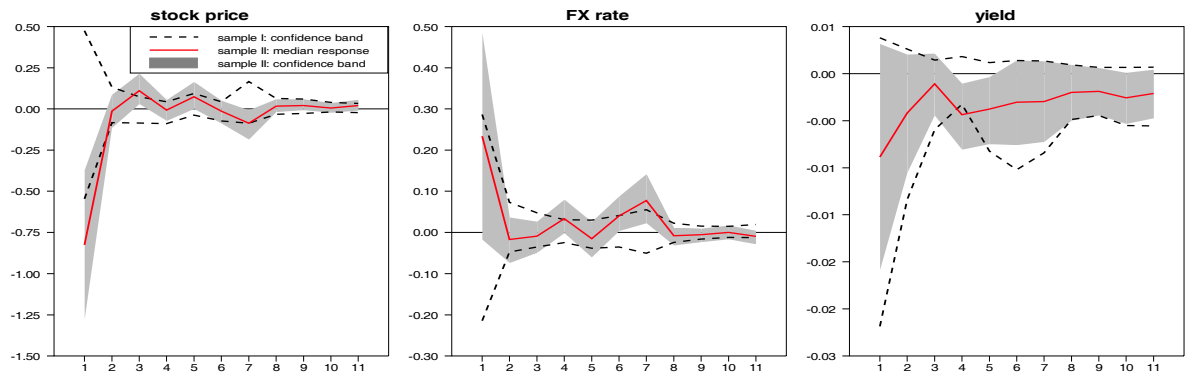

b. Chile
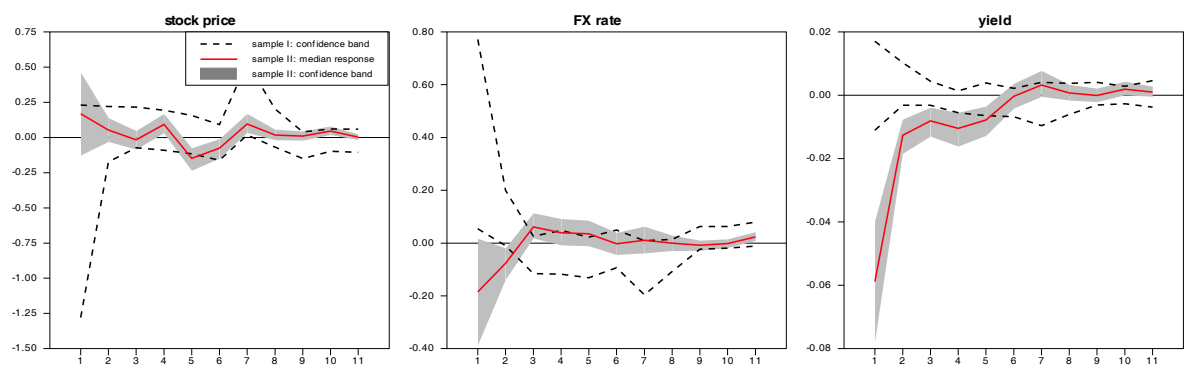

c. Czech Republic
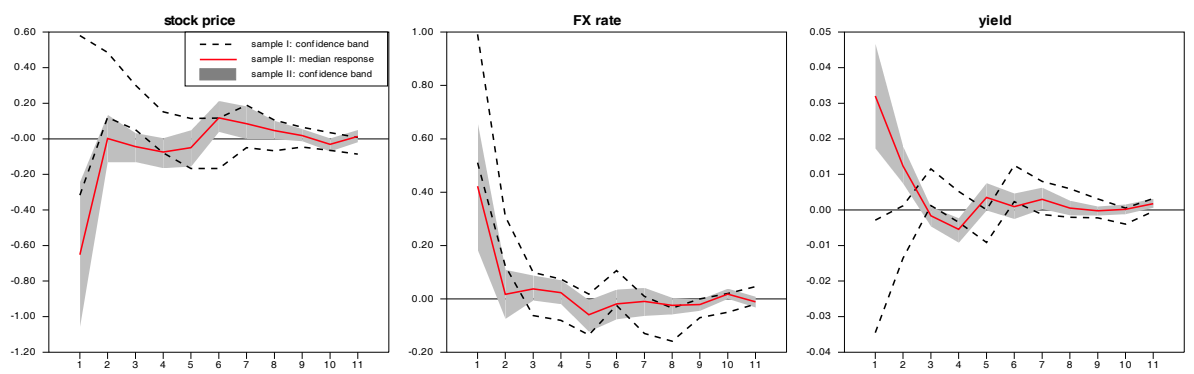

d. Hungary
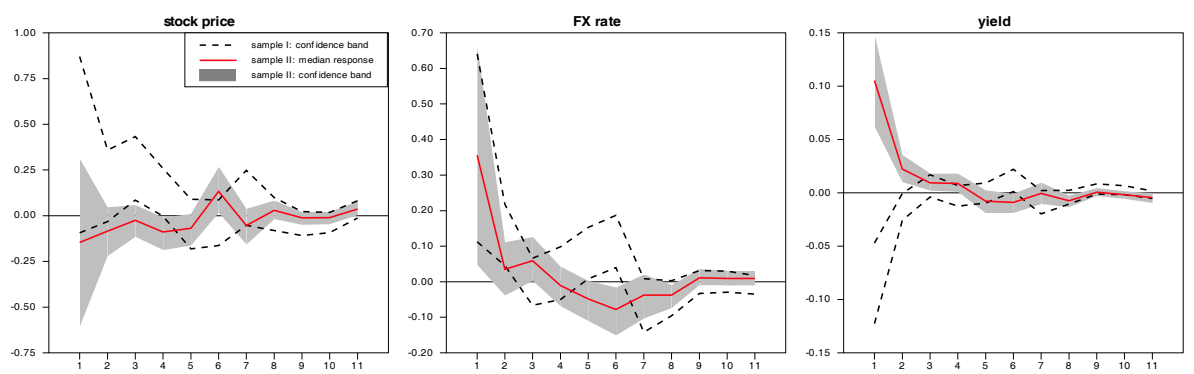
e. Indonesia
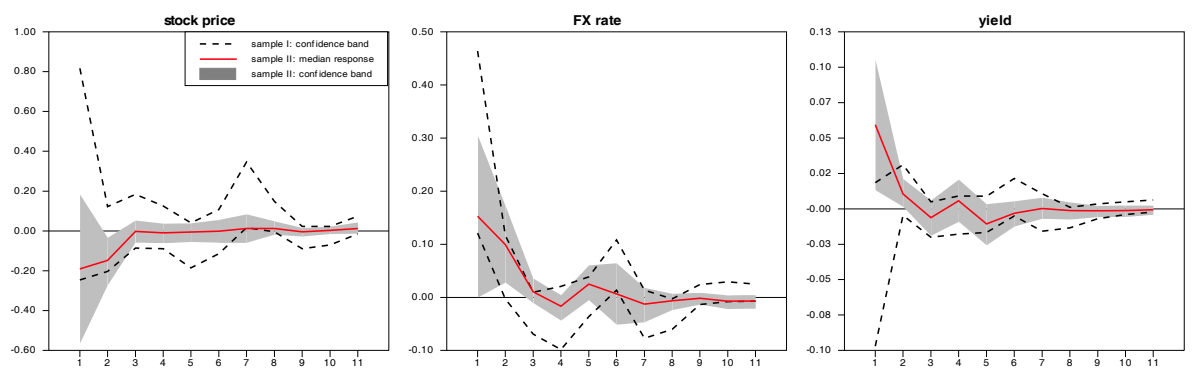

f. Korea
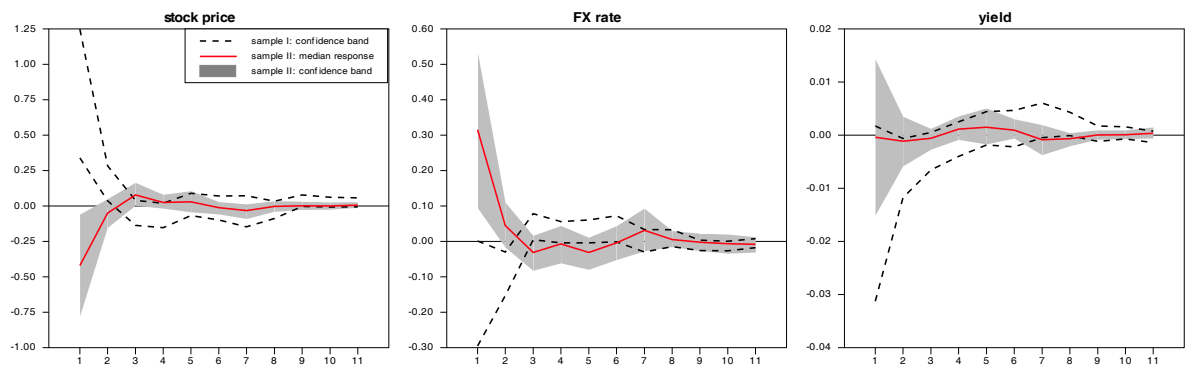

g. Malaysia
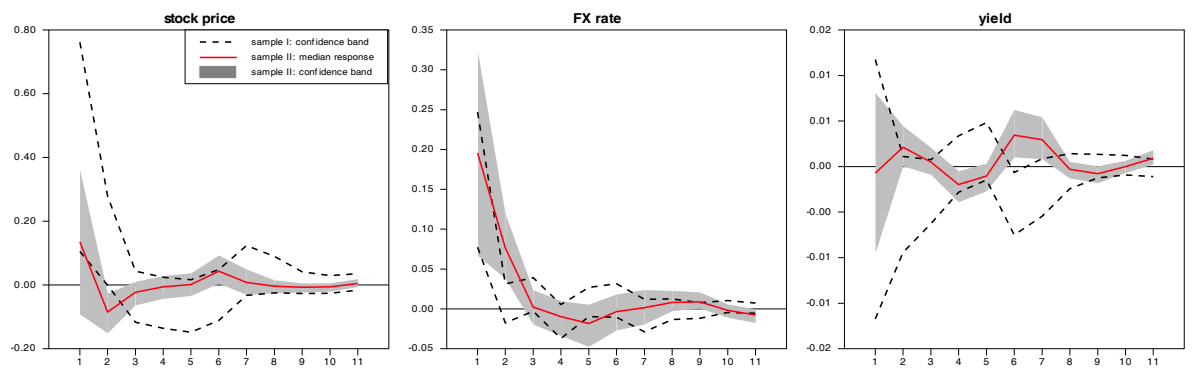

h. Mexico
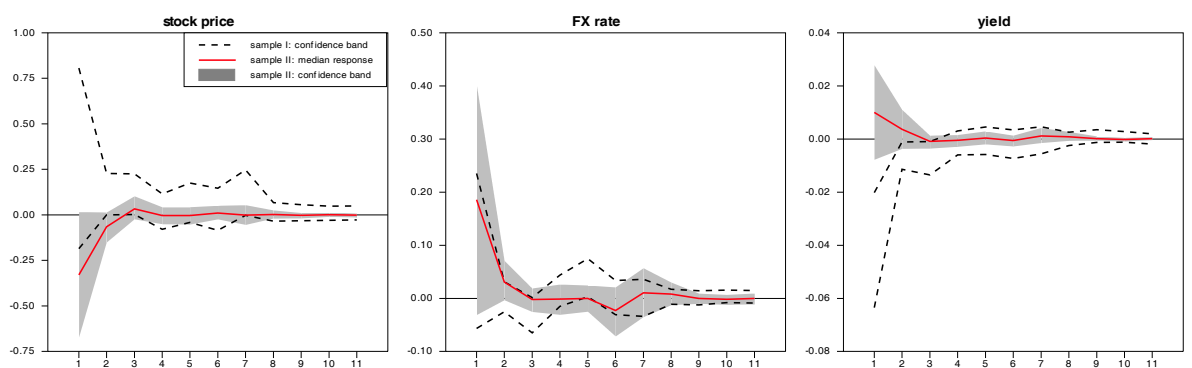


\section{i. Philippines}
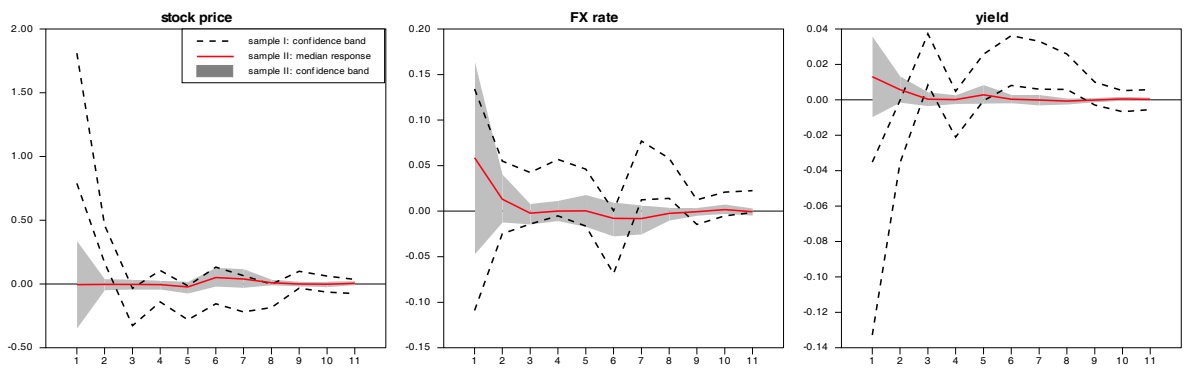

j. Poland
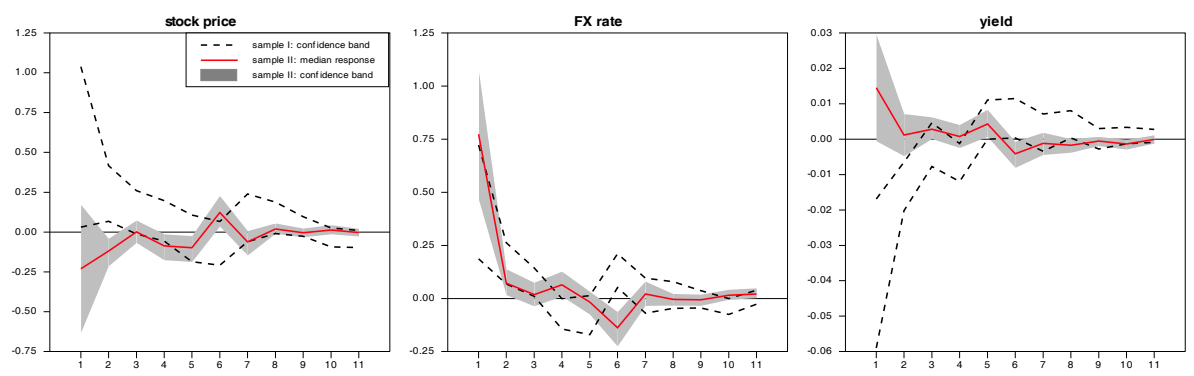

Notes: Sample I covers 2004.1-2008.8 and sample II covers the period of 2008.11-2014.12. The bootstrapped confidence bands indicate the 0.16 and 0.84 percentiles of the draws.

invest in mature economies and leave emerging economies. The consequence would be a drop in asset prices, a nominal devaluation and an increase in bond yields and monetary conditions tighten. There is, however, an alternative transmission channel. If the U.S. tightens, this is indication of favorable macroeconomic conditions today, i.e. strong real growth. In a world economy connected by strong trade ties, this is beneficial for export-oriented emerging economies because global demand is high. As a consequence, a tightening in the U.S. could well be associated with an increase in emerging markets' stock prices. Emerging economies exhibit changes in the signs of the responses to U.S. policy depending on which of these two alternative transmission channels dominates. In emerging bond markets, the responses to U.S policy shocks also reveal opposite signs in several countries including the Czech Republic, Hungary, Indonesia, and Poland. One possible explanation of this differentiated transmission effect is that 
the target of EMEs' policy responding to U.S. interest rate shocks differ by countries: that is, for some countries, containing inflationary pressure is the main policy goal where raising policy rates lowers inflation, leading to drops in long-term bond rates, while in others alleviating real economic contraction is more important, so cutting policy rate leads to lower bond rates without upward inflationary pressure.

A third observation pertains not only to the signs of the responses change across sample periods, but also the magnitude of the responses. Somewhat surprisingly, we find that the responses are broadly similar in magnitudes in the second sample compared to the first. Take Brazil, Figure (2a), or Korea, Figure (2f), as examples. In both countries the magnitude of the responses does not systematically increase in the second sample. In this sense the idea of a "New Normal" (Aizenman, Chinn and Ito, 2015) of spillovers after the crisis should be used to describe the size of the spillovers. As a matter of fact, the spillovers perceived by emerging market economies are the product of the size of the spillovers and the size of the monetary policy change in advanced economies. During and after the financial crisis, the latter component was exceptionally large, while the first appears to be unchanged.

The wide disparity of spillovers, both in terms of magnitudes and directions, is certainly linked to underlying economic fundamentals. Below we will link this heterogeneity with countries' fundamental macroeconomic weaknesses. Before that, however, we will discuss the asymmetry of spillovers in some detail.

\subsection{An alternative measure of U.S. monetary policy}

As mentioned before, we also use the change in the (shadow) Federal Funds rate itself as a measure of U.S. policy in our VAR-X model. We use change of the Wu-Xia shadow rate. To save space and to facilitate a comparison of the responses across the two sample periods, across the sample countries and across the variables used to measure U.S. policy, Figures (3) depicts the accumulated responses for each variable and each country in both samples. The responses are cumulated for ten observations. 
Figure 3: Cumulated Impulse Responses of Financial Variables to the $0.25 \% \mathrm{p}$ Increase in the Wu-Xia U.S. Shadow Rate
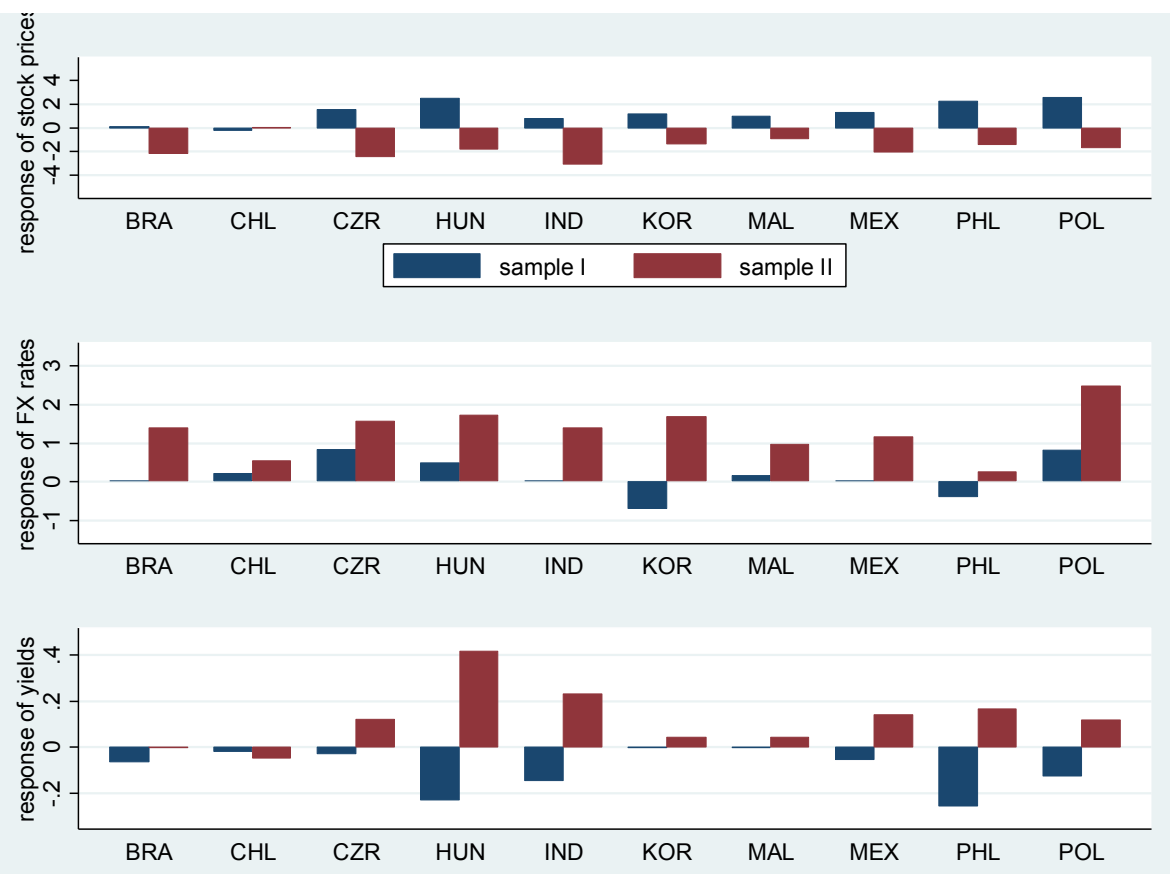

Note: Sample I covers 2004.1-2008.8 and sample II covers the period of 2008.11-2014.12.

For change in the Wu-Xia shadow rate, see Figure (3), our VAR-X shows that in sample II all stock prices fall after a monetary policy change. Furthermore, in sample II all exchange rates exhibit a depreciation after a Fed tightening. Overall, the effects on the exchange rate are unanimously stronger in the second sample. While the results are more clear-cut compared to our primary findings obtained from the shock component of the Wu-Xia shadow rate only, we believe the shock component is a conceptually more appealing measure of U.S. monetary policy.8)

8) Of courses, the results of this estimation may differ depending on the methodology of obtaining the shadow rates. For example, we can see quite different pattern in the impulses responses when we employ the Krippner shadow rate. See the Appendix for the results with Krippner shadow rates. Some authors such as Lombardiand Zhu (2014) propose a methodology employing a factor model to include a large set of financial data. 


\subsection{Different effects of tightening and easing shocks? An asymmetric VAR-X model}

The previous sections have highlighted the time-variation in international policy spillovers. In this section we will study whether the international spillover effects from tapering unconventional policies are larger than those from announcing QE. Put differently, we ask whether the absolute effect of a tightening shock is different from the absolute effect of an easing shock. The existing literature on the domestic transmission of monetary policy evokes the metaphor of "pulling versus pushing a string" (Tenreyro and Thwaites, 2015). In a boom phase, monetary policy "pulls on a string" and the economy contracts. In a recession, policy pushed on that very same "string" - which is clearly less effective. The result is an asymmetric domestic transmission mechanism. Here we ask whether we see a similar asymmetry on a global scale.

Gambacorta and Rossi (2007) estimate an asymmetric vector error-correction model to show that positive and negative shocks have different effects on bank lending. In a semiparametric time series model, Angrist et al. (2014) find that tightening (conventional) monetary policy is more effective than easing policy. Likewise, Barnichon and Matthes (2014) estimate a structural VAR model with impulse responses parameterized by Gaussian basis functions and come to similar findings. In a recent contribution, Tenreyro and Thwaites (2015) corroborate this view based on a series of anecdotal monetary policy shocks.

The problem of "pushing on a string" is particularly relevant for unconventional monetary policies which were implemented in severe recessions. Rogers et al. (2014) estimate a single-equation framework for domestic effects of unconventional monetary policy allowing for asymmetries and find that the effect of expansionary policy on stock returns is larger in magnitude than the negative impact of a surprise tightening. Hence, according to their findings, there is now distinction between the effectiveness of tightening and easing. Fratzscher et al. (2013) study this issue in light of the spillover effects of unconventional policies. These authors find that an expansionary, unconventional policy has stronger effects on stock markets and capital inflows (measures by high-frequency inflows into equity funds) than an identically sized contractionary shock. 
Taken together, the evidence for asymmetries of $\mathrm{QE}$ in the sense of different effects of tightening and easing steps is mixed. Therefore, we extend our model to evaluate whether the countries in our sample experienced asymmetric spillover effects. We estimate a modified VAR-X model, which we refer to as an Asymmetric VAR-X model or AVAR-X. The model is

$$
Y_{t}=A_{0}+A(L) Y_{t}+b^{\text {tight }} \times \Delta R_{t, t i g h t}^{\text {shock } U S}+b^{\text {ease }} \times \Delta R_{t, \text { ease }}^{\text {shock } U S}+\varepsilon_{t} .
$$

In this model, we split the exogenous shadow rate into rate increases and decreases, respectively.9) The variable $\Delta R_{t, t i g h t}^{\text {shock, }}$ (S) reflects a tightening of U.S. monetary policy, i.e. a positive shock component of the change in the shadow policy rate in period t, while $\Delta R_{t, \text { ease }}^{\text {shos } U S}$ stands for an easing of monetary policy in the U.S., i.e. a decrease in the shock component of the shadow rate. The coefficients $b^{\text {tight }}$ and $b^{\text {ease }}$ indicate the impact effect of tightening and easing steps of the Fed, respectively, on emerging economies. The model provides a convenient way to disentangle periods of easing and tightening conditions. This models collapses to the model used in the previous conditions if we set $b^{t i g h t}=b^{\text {ease }}$. To highlight the differences with respect to the policy stance, we focus on the second sample period, which witnessed a dramatic easing of policy and the subsequent tightening. We expect that, in general, tightening shocks incur lower stock prices, higher bond rates, and a depreciation in EMEs' currencies. If spillovers are symmetric, easing shocks have opposite signs. However, as we discussed in previous section, the impacts can vary according to EMEs' macroeconomic situation and their policy goals at that time.

The results are again visualized by impulse response functions. Figures (5a) to (5j) depict the responses to a tightening of U.S. policy, i.e. a shock of $+0.25 \mathrm{pp}$ (shaded area), and an easing shock, i.e. a shock of -0.25pp (dotted lines). Thus, the maximum degree of asymmetry is obtained when both a tightening shock and an easing shock lead to the same impulse response pattern. The sensitivity is

9) Bassett et al. (2010) also study asymmetries in their VAR-X model. They focus on tightening and easing shocks to credit standards. Their findings suggest that tightening shocks have the expected signs, while easing shocks lead to insignificant estimates. 
Figure 5: Responses of EMEs to a Tightening vs. an Easing Shock of $0.25 \% p$ in the Post-2008 Sample: Asymmetry

a. Brazil
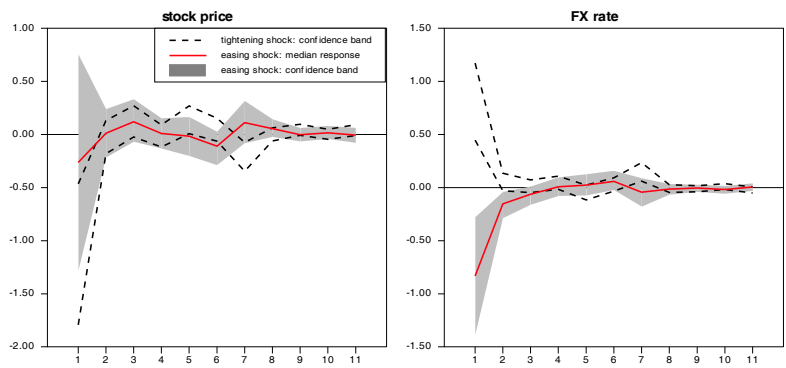

b. Chile
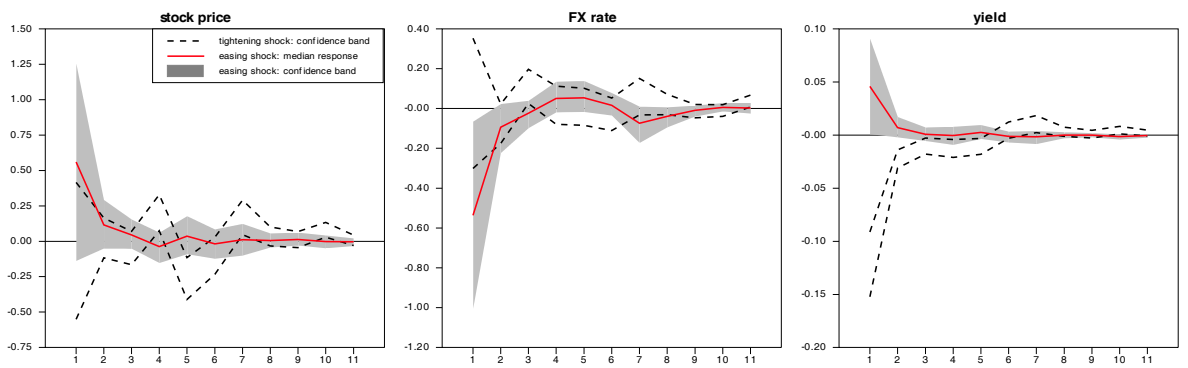

c. Czech Republic
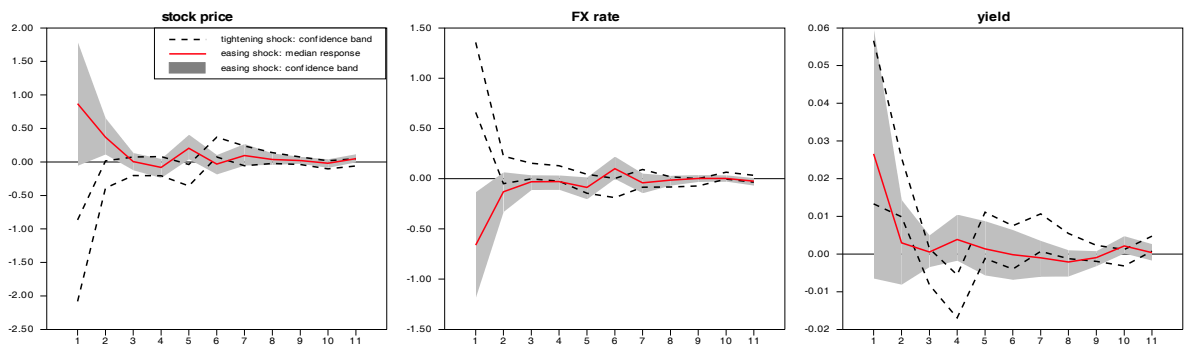

d. Hungary
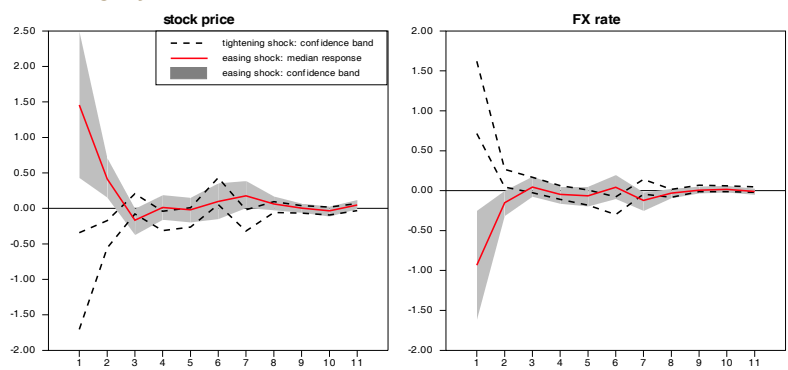
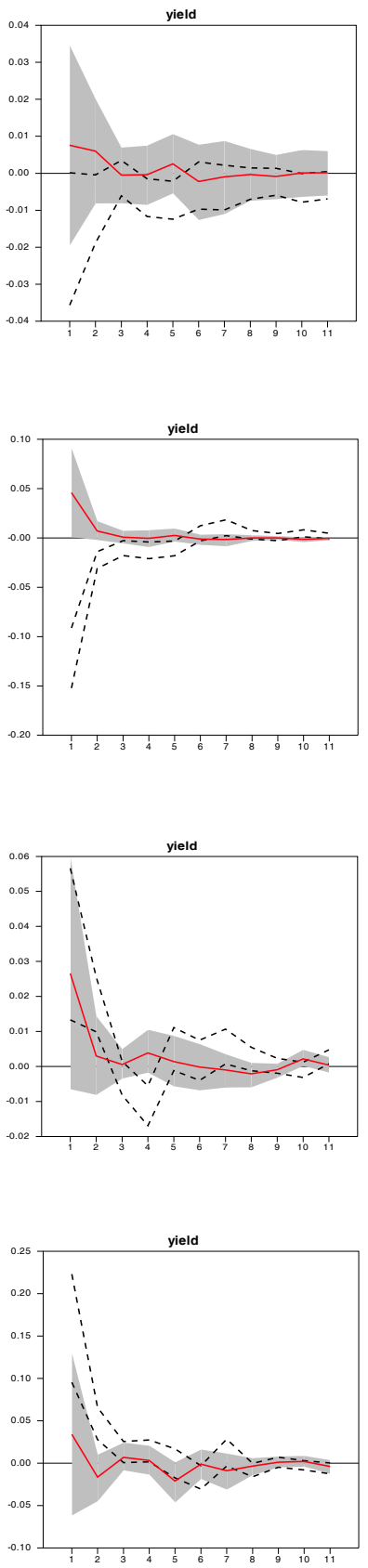
e. Indonesia
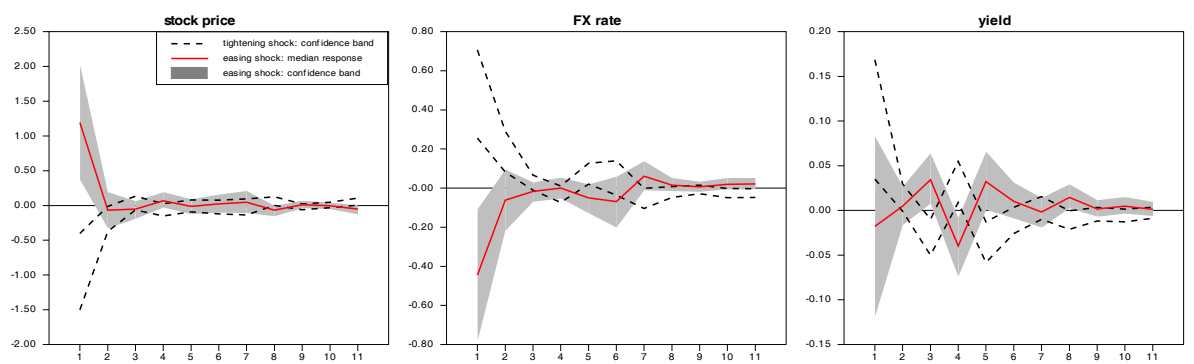

f. Korea
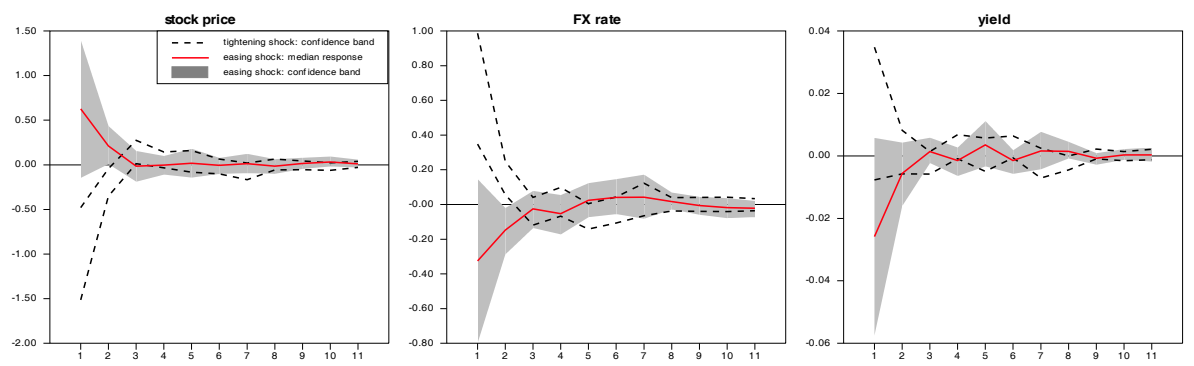

g. Malaysia
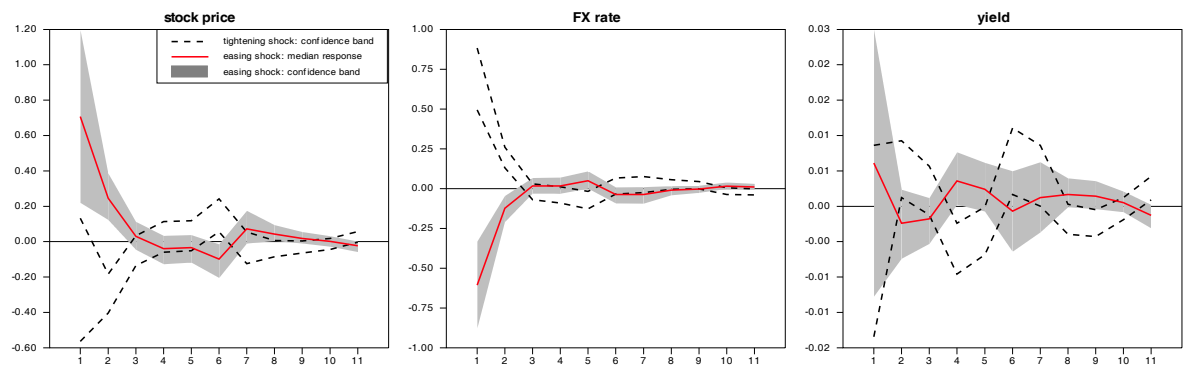

h. Mexico
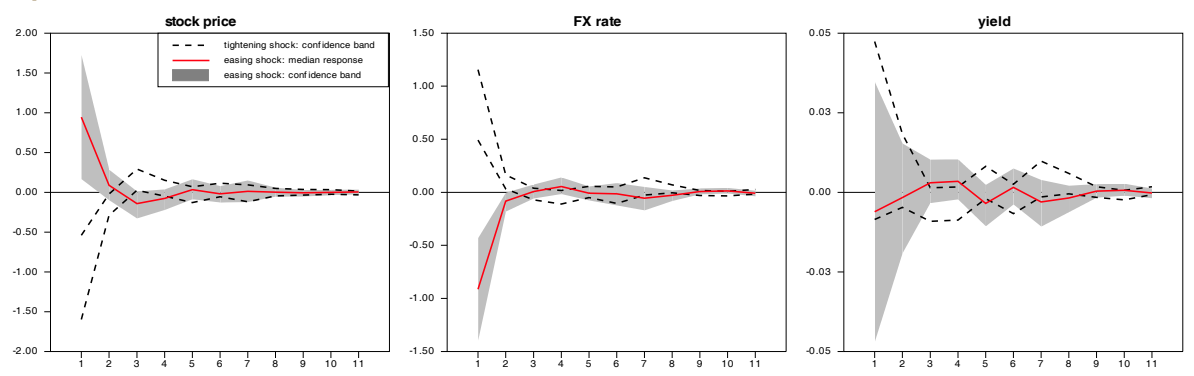


\section{i. Philippines}
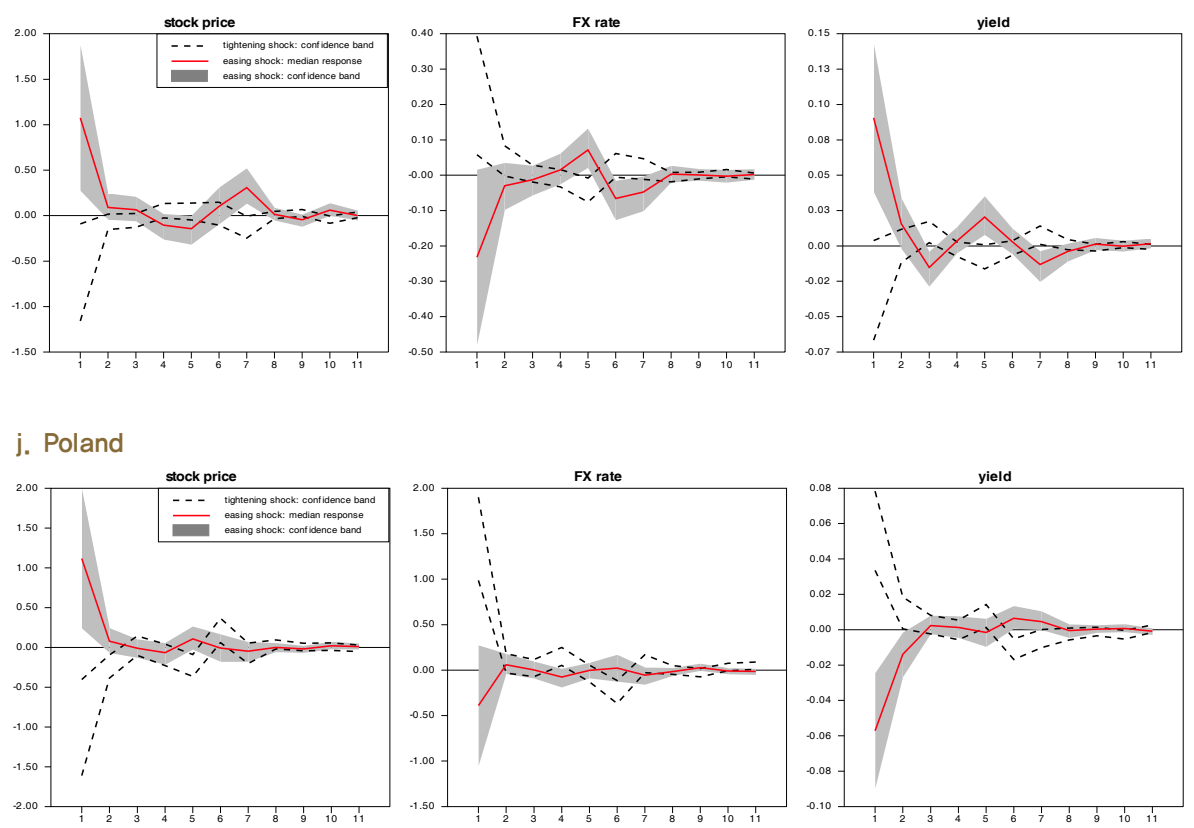

perfectly symmetric if both responses have the same dynamics with opposite signs. The results highlight strong asymmetries pertaining to the sign, the size and the shape of the responses to tightening and easing shocks. These asymmetries also explain some of the insignificant and inconclusive response we have obtained from the linear VAR-X model.

We explain the asymmetries with reference to the results for Korea, Mexico and Poland. In Korea, see Figure (5f), a tightening in the U.S. leads, as expected, to a fall in stock prices by $1 \%$ to $1.5 \%$. An easing of the same size, however, leads to an increase in stock prices of only $0.6 \%$, which is insignificantly different from zero. Hence, spillovers are twice as strong after a policy tightening. Comparing the point estimates for the response of the KRW, we find that the appreciation resulting from an easing by the Fed is smaller than the depreciation resulting from a Fed tightening. Both a tightening and an easing leads to a small but insignificant increase in Korean bond yields. For Mexico, see Figure (5h), we find that the responses of stock prices and the exchange rate are quite symmetric. 
Bond yields do not respond, either to a tightening or an easing shock, respectively. For Poland, see Figure (5j), a policy tightening seems to have much larger consequences for the exchange rate than an easing of the Fed. Following a tightening, the Polish currency depreciates by $1.5 \%$ while an easing leaves the exchange rate unaffected. We conclude that for many countries the spillovers exhibit an important degree of asymmetry. The evidence suggests a small tendency for a U.S. tightening (e.g., QE tapering) being more effective on emerging financial markets than an easing (e.g., introducing QE) of similar magnitude. That would mean that the notion of "pushing on a string" might also be a good metaphor for international spillover effects of monetary policy.

The previous results on asymmetric spillovers were derived from the post-2008 sample period. Figure (6) presents the cumulated responses of each endogenous variable in each country to positive and negative U.S. monetary policy shocks, respectively. The figure shows that both tightening and easing shocks have become more important for emerging markets in the second sample compared to the first. The degree of asymmetry, i.e. the comparison between the pairs of two light colored and dark colored responses, exhibits a few interesting patterns. For stock prices in the second sample, we find that in many countries a U.S. tightening shock has larger effects on emerging markets than an easing shock of identical size. In Mexico, e.g., a tightening reduces stock prices by roughly one percent, while a policy easing raises stock prices raises stock prices by less than one percent. Hence, the coming tightening cycle of the Federal Reserve will put relatively more pressure on EME's stock prices than the introduction of $\mathrm{QE}$ some years ago. For some countries (IND, KOR, MEX and PHL) we find that in the first sample the asymmetry of the responses is much larger than in the second sample. For these countries both a tightening and an easing shock lead to an increase in domestic stock prices.

As regards the response of the exchange rate, our results suggest that for BRA, CHL, CZR, HUN, IND, MAL and MEX an easing of monetary conditions in the U.S. has larger consequences than a tightening. For KOR and POL we find the opposite, i.e. a tightening leads to a depreciation that is larger in absolute terms that the devaluation following an easing shock. 
Figure 6: Cumulated Responses of EMEs' Financial Variables to a Tightening and Easing Shock of $0.25 \%$ p in the Pre- and Post-2008 Samples
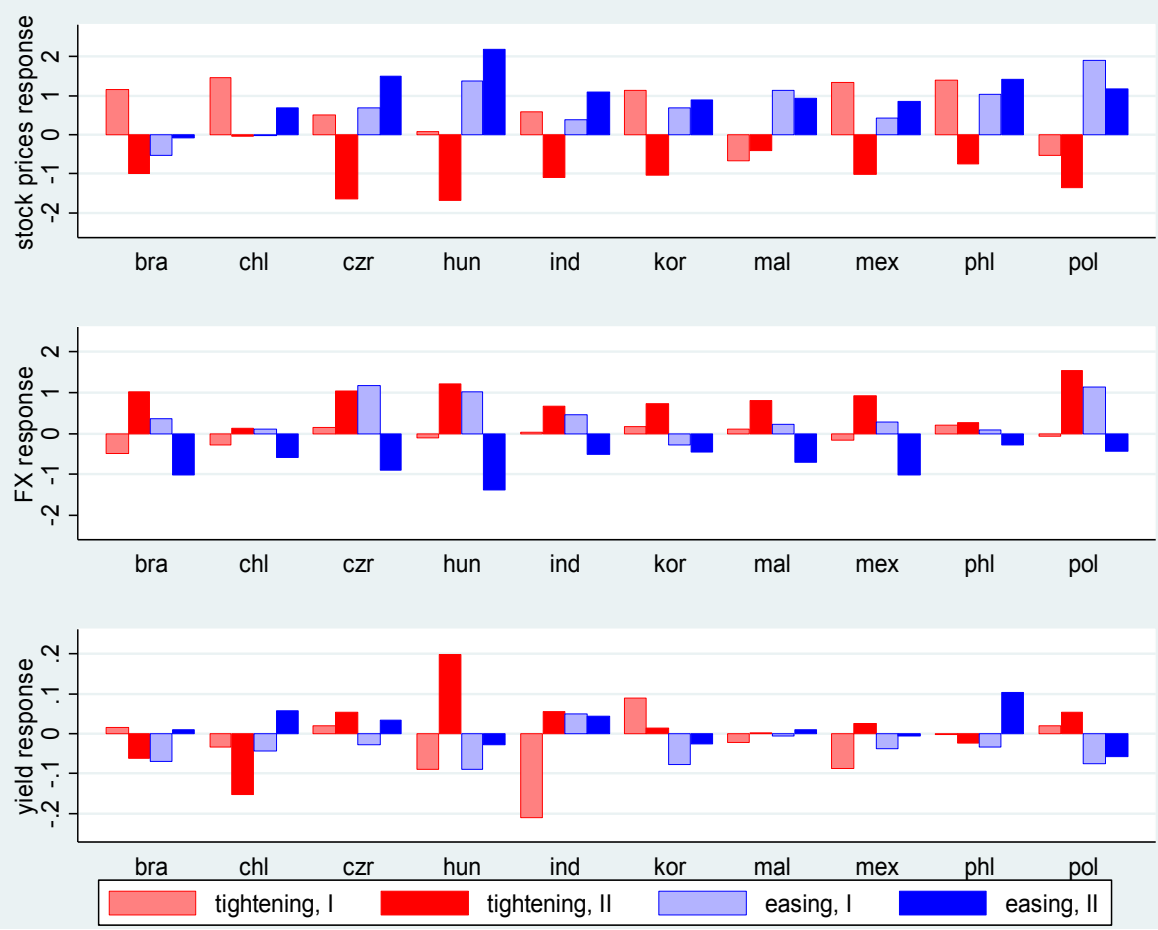

Note: The bar represents cumulative responses for a horizon of 10 weeks.

\section{The Role of Macroeconomic Fundamentals}

It is clear that domestic macroeconomic fundamentals play a key role for the sensitivity of emerging countries to foreign policy spillovers. Recent work by Ahmed et al. (2015), Georgiadis (2015) and others show that the exposure to spillovers depends on fundamentals, with the strength between fundamentals and spillovers varying strongly across countries.

It remains to analyze whether the magnitude and the sign of the spillovers estimated in this paper are reflecting macroeconomic conditions. For that purpose, we first obtain the cumulative impulse responses for each of the three 
endogenous variables over 10 periods following a tightening shock. Note that for this analysis we no longer differentiate between a tightening and an easing shock as the model we use is linear. This is done for all countries and the two sample periods: 2004 - 2008 (sample I) and 2009- 2014 (sample II). In a second step, we relate these cumulative responses to fundamentals. For every of the 10 countries, we collect data on the current account balance relative to GDP, the external indebtedness of the government relative to GDP, the level of foreign exchange reserves to GDP, the degree of openness in terms of exports and imports and the level of the country's CDS spreads as a measure of its default risk. These indicators are averaged over the two sample periods and related to the accumulated impulse responses discussed before.

The scatter plots in Figures (7a) to (7e) show that the magnitudes of the impulse responses vary with fundamentals. In all figures we also plot a regression line together with $95 \%$ confidence bands. As a matter of fact, the simple bivariate relationship between responses and fundamentals is far from perfect. Nevertheless, it allows us to extract a few clear patterns. We believe a regression of impulse responses on fundamentals is not feasible due to the small number of observations. Take the level of external debt to GDP in sample II as a fundamental, see Figure (7a). The more indebted a country is, the stronger is the depreciation pressure on the currency upon tightening policy shocks in sample I. For the second sample we also find that the higher the debt level, the more sensitive is the response of bond yields to policy shocks. For stock prices we find positively sloped connection to fundamentals only in the first sample period. In the second, the slope is roughly zero.

Figure (7b) reveals that the strength of the spillovers since the financial crisis is associated with the current account positions. The more the country's external position is in deficit, the more negative the response of stock prices in the second sample. For the exchange rate, the role of current account imbalances is present in both subsamples: The more the current account is in deficit, the stronger the depreciation of the national currency. The larger the current account deficit, the larger is the fall in bond yields in sample I.

Figure (7c) plots the responses against the ratio of foreign exchange reserves to 
Figure 7: Cumulated Impulse Responses Against Fundamentals

a. Fundamental: external debt to GDP
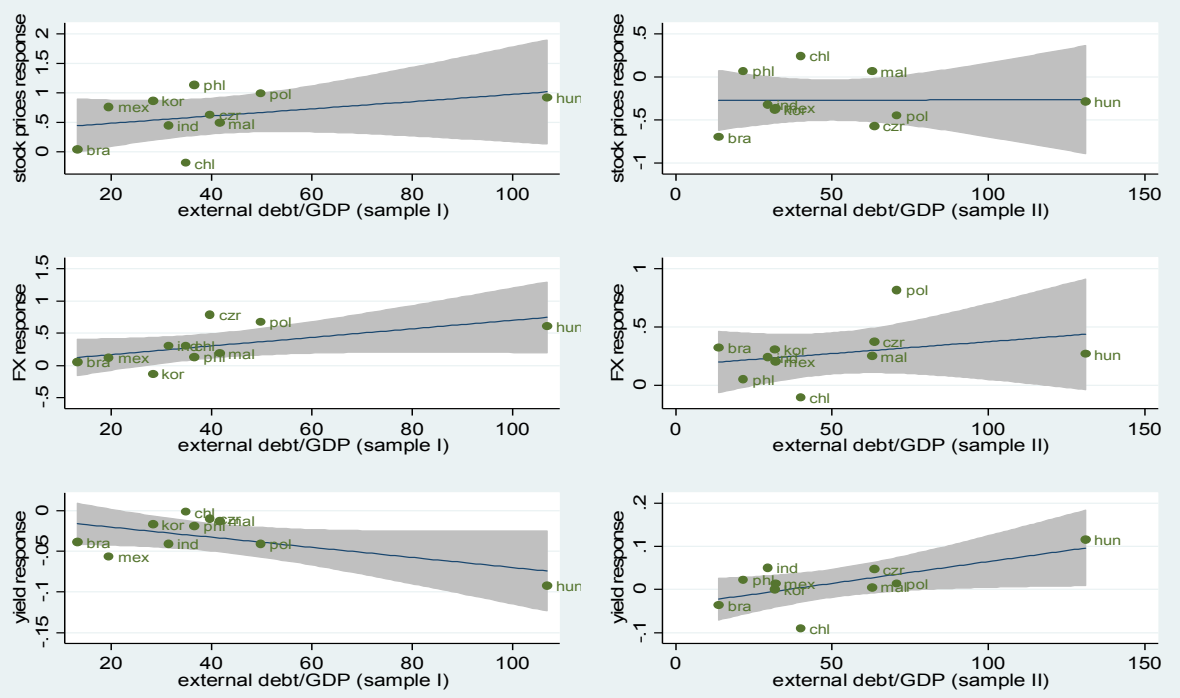

b. Fundamental: current account to GDP
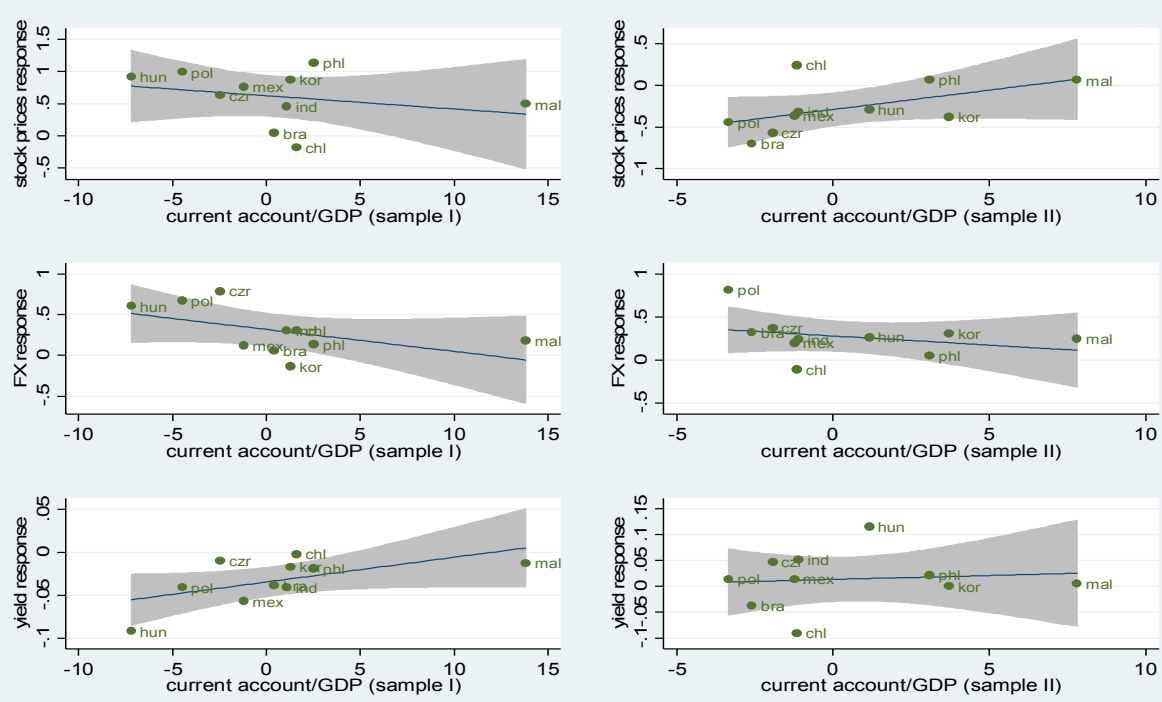
c. Fundamental: reserves to GDP
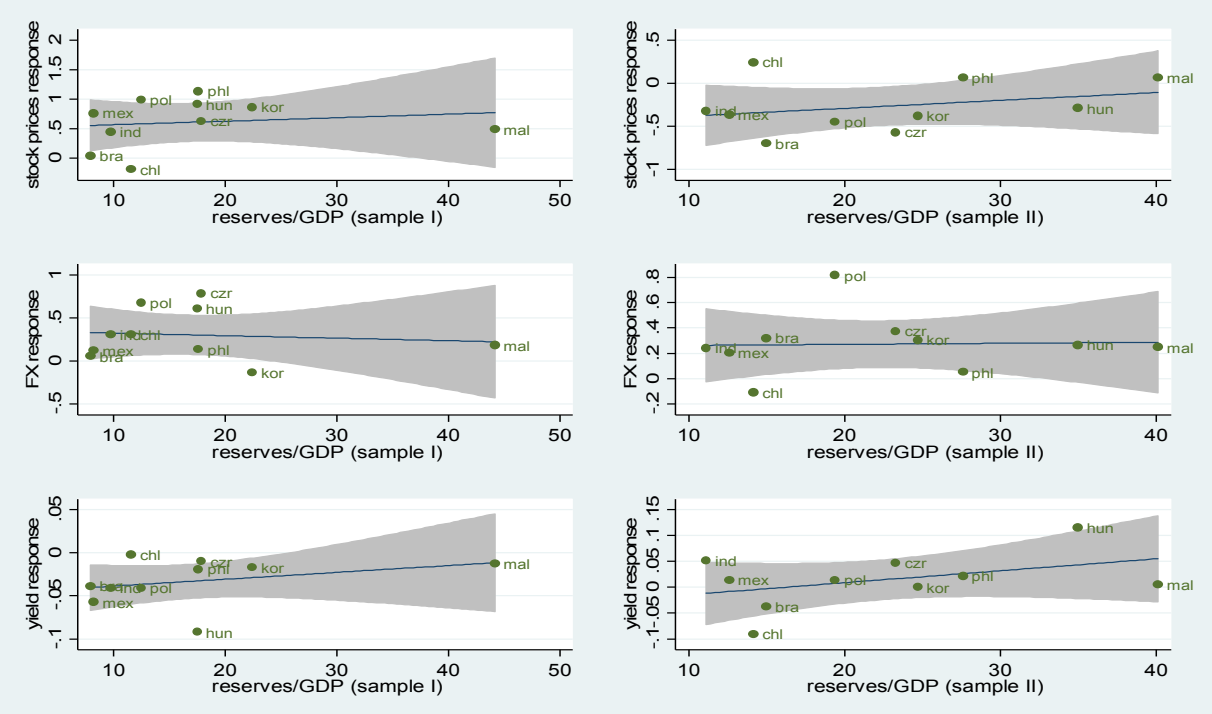

d. Fundamental: economic openness
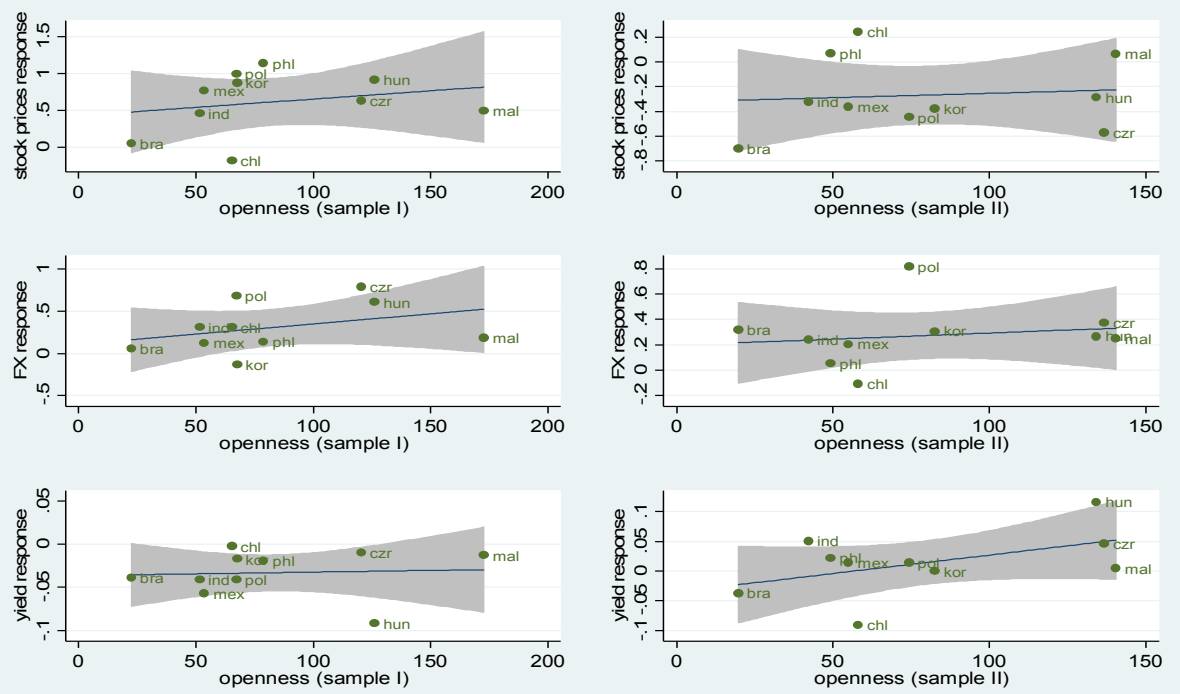

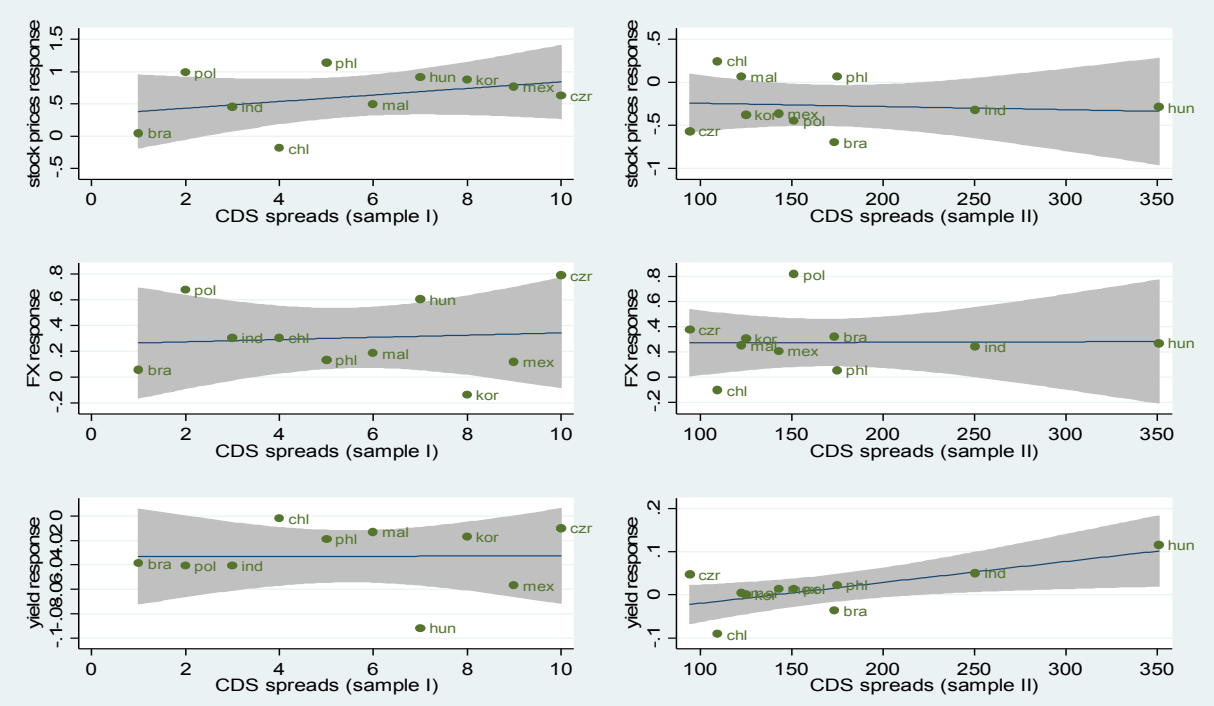

Notes: The dots represent the relationship between each countryís fundamental and the size of cumulative responses to U.S. monetary tightening shocks. The $95 \%$ confidence bands are plotted as two standard errors around the mean, where the standard errors are obtained from the OLS estimation of the regression line.

GDP. For all combinations of variables, samples and fundamentals, the slope of the regression line is hardy distinguishable from zero. Only for stock prices in sample II the reserve ratio offers some explanatory power: the lower reserves, the larger the fall in stock prices if the U.S. tightens.

For economic openness as a fundamental factor, see Figure (7d), we find that the sensitivities of bond yields in sample II and exchange rates to U.S. policy in sample I increase with openness - a finding that is highly plausible.

The average CDS spread, see Figure (7e), exhibits the largest explanatory power for bond yields in sample II. The higher the default risk, the more do bond yields respond to U.S. policy. For most other variables' responses the CDS spread is a less relevant explanatory factor.

We can summarize the main implications from this analysis as follows: a "lift-off" of the Federal Funds rate in 2015/16 will put pressure on bond yields of countries with high CDS spreads, a high external indebtedness and a high degree 
of openness. Likewise, stock prices will suffer from the retrenchment of capital flows following "lift-off" if they have a high current account deficit and low levels of reserves.

Among our countries are Indonesia and Brazil, which were part of the set of "fragile five" emerging economies, together with India, Turkey and South Africa. The fragile five came under hefty pressure in 2013 when the Fed started to unwind its unconventional measures. Our results corroborate the view that these countries are among the countries most prone to spillover effects. Brazil and Indonesia had high current account deficits, relatively few reserves and experienced a strong depreciation. Moreover, their sovereign CDS spreads are topped only by those of Hungary, thus implying a strong effect of Fed tightening on domestic bond yields.

To summarize the role of fundamentals, we organize the impulse response functions according to the fundamental position of each economy, that is, we present an impulse response for "weak" economy and average "strong" economies, where we classify a country's fundamental position according to different fundamentals. For each of the fundamentals (current account to GDP, reserves to GDP, external debt and CDS spread, each of which is averaged over the second sample) we order the countries according to whether their fundamentals are above or below the median country.

In the former case a country is considered "strong" while in the latter the country is considered "weak."10) Finally, we average the impulse responses within the group of weak and strong economies, respectively, where we focus only on the three weakest and three strongest countries. This gives us five sets of impulse responses, one for each fundamental, where in each graph we see both responses for strong and for weak economies.

The results are shown in Figures (8). The strong economies are represented by the shaded area while the weak economies' responses correspond to the dotted lines. We see that the fundamental position matters for the FX rate and the yield responses, but to a smaller extent for the stock price response. In most cases,

10) Of course we take into account that for some fundamentals, being below the median signals stronger fundamentals, e.g., for CDS spreads, indebtedness and others. 
Figure 8: Responses for Countries with Weak and Strong Fundamentals to an U.S. Shock of $0.25 \%$ p in the Post-2008 Sample

a. Fundamental: current account balance to GDP
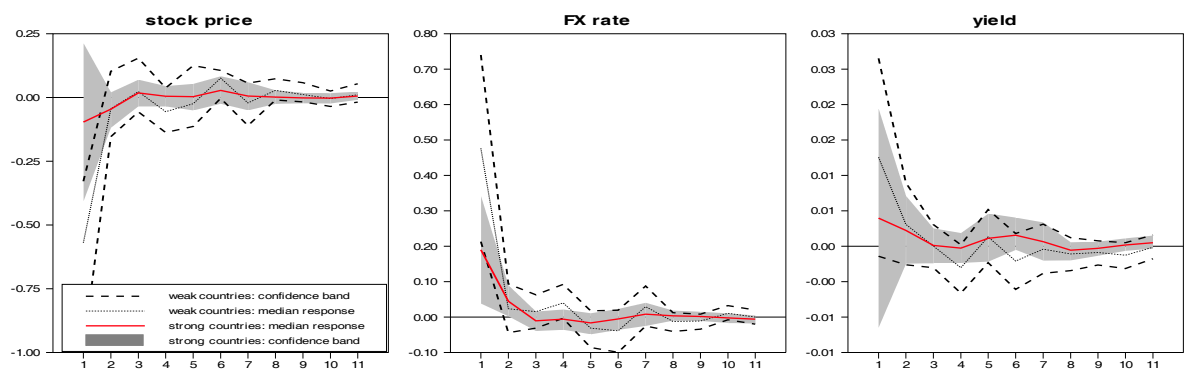

b. Fundamental: government debt to GDP
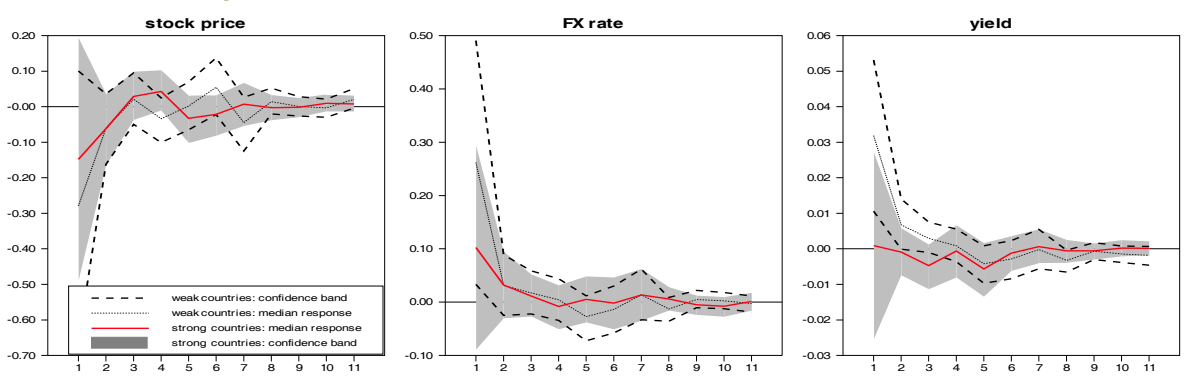

c. Fundamental: reserves to GDP
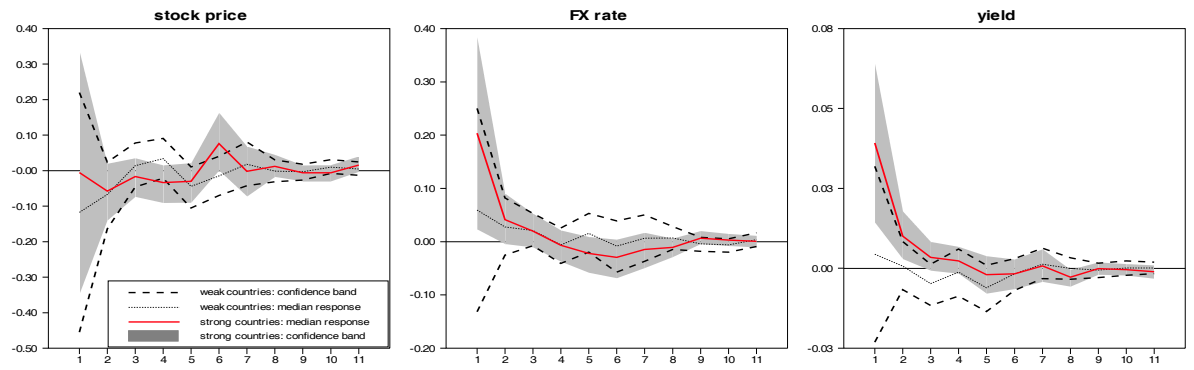

d. Fundamental: external debt to GDP
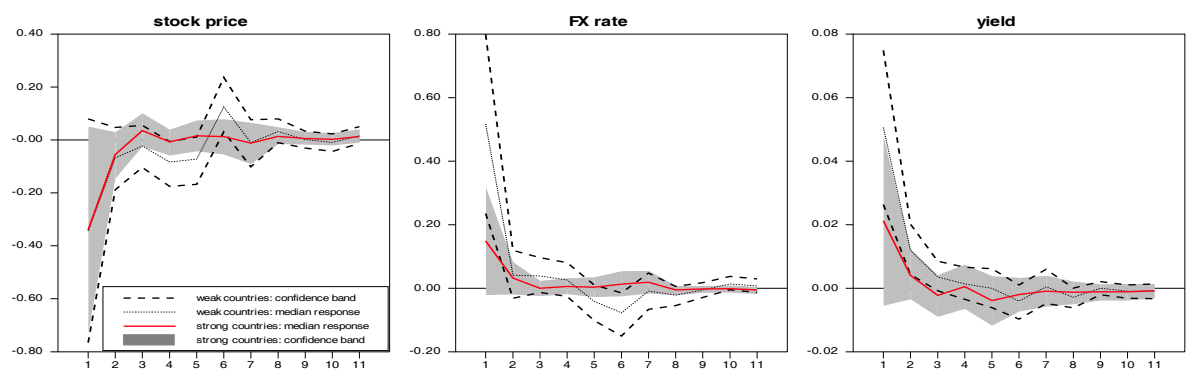
e. Fundamental: CDS spread
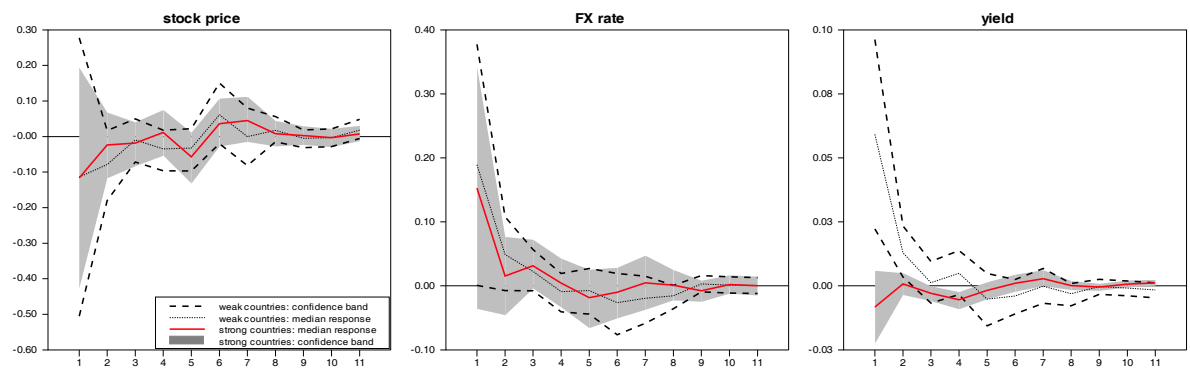

Note: Bootstrapped confidence bands indicate the 0.16 and 0.84 percentiles of the draws.

fundamentally weak economies exhibit a substantively stronger depreciation and stronger increase in domestic bond yield than fundamentally strong economies. The median response for the group of the three strongest economies lies outside the confidence band surrounding the response of the group of weak economies. From that we can conclude that fundamentals indeed matter much for explaining a country's exposure to spillovers.

\section{Conclusions}

In this paper we studied the spillover effects of conventional and unconventional monetary policy in the U.S. on a set of 10 emerging market economies. For this purpose we estimated a range of VAR models in which U.S. monetary conditions entered exogenously. Our primary measure of U.S. policy is the identified shock component of the shadow Federal Funds rate. This gives us an estimate of policy shocks that is consistent with both conventional and unconventional monetary policy.

We derived three key findings. (1) The size and the sign of spillover effects on domestic equity returns, exchange rate changes and changes in bond yields vary across regimes, and there is no common pattern of spillovers. We also do not find that spillovers are systematically higher after the global financial crisis. (2) Allowing the transmission of policy shocks to be asymmetric, we find that a U.S. tightening has stronger impacts on emerging financial markets than an easing 
policy does. In this aspect, the discussion of spillover effects should acknowledge the fact that tightening and easing shocks originating in the U.S. can lead to highly asymmetric spillover effects. (3) The sensitivity of emerging market economies to U.S. policy is related to the fundamental weakness of the economy. An increase in several macroeconomic weakness indicators such as the current account deficit relative to GDP or the external indebtedness leads to larger spillovers.

Our results have policy implications for the Fed's and other central banks' lift-off from the zero lower bound. When the Fed raises the Federal Funds rate for the first time since 2006 , emerging market economies will be hit. In fact, the anticipation of the lift-off in recent month has put emerging markets under pressure - very much in line with our model in which it is the surprise component of the shadow rate that drives emerging markets' financial conditions. Eventually, also the Bank of England, the Bank of Japan and the European Central Bank will exit from unconventional policies and will tighten monetary conditions further by raising interest rates. Our results also suggest that the nonlinear and asymmetric nature of spillovers makes the design of appropriate macroprudential policies challenging, if not impossible. A macroprudential policy instrument has to be adjusted in order to address the waves of capital flows resulting from policy spillovers. It remains to be seen whether macroprudential policy can accomplish that. Our preferred policy response could aim at keeping the economy fundamentally sound. We showed that an economy with strong fundamentals is best prepared to withstand most of the externalities of advanced countries' monetary policy. 


\section{References}

Ahmed, S., B. Coulibaly, and A. Zlate (2015), "International Financial Spillovers to Emerging Market Economies: How Important are Economic Fundamentals?" International Finance Discussion Papers, No. 2015-1135, Washington, D.C.: Board of Governors of the Federal Reserve System.

Aizenman, J., M. D. Chinn, and H. Ito (2015), "Monetary Policy Spillovers and the Trilemma in the New Normal: Periphery Country Sensitivity to Core Country Conditions," NBER Working Paper, No. 21128.

Angrist, J. D., O. Jorda, and G. Kuersteiner (2014), "Semiparametric Estimates of Monetary Policy Effects: String Theory Revisited," Working Paper, No. 2013-24, Federal Reserve Bank of San Francisco.

Barnichon, R., and C. Matthes (2014), "Measuring the Non-linear Effects of Monetary Policy," 2015 Meeting Papers, No. 49, Society for Economic Dynamics.

Bassett, W. F., M. B. Chosak, J. C. Driscoll, and E. Zakrajsek (2010), "Identifying the Macroeconomic Effects of Bank Lending Supply Shocks," Working Paper, Federal Reserve Bank of Kansas City.

Chen, J., T. Mancini-Griffoli, and R. Sahay (2014), "Spillovers from United States Monetary Policy on Emerging Markets: Different This Time?" IMF Working Paper, WP/14/240.

Chen, Q., A. J. Filardo, D. He, and F. Zhu (2015), "Financial Crisis, U.S. Unconventional Monetary Policy and International Spillovers," Journal of International Money and Finance (forthcoming).

Francis, N. R., L. E. Jackson, and M. T. Owyang (2014), "How Has Empirical Monetary Policy Analysis Changed After the Financial Crisis?" Working Paper, No. 2014-019A, Federal Reserve Bank of St. Louis.

Fratzscher, M., M. Lo Duca, and R. Straub (2013), "On the International Spillovers of U.S. Quantitative Easing," European Central Bank Working Paper, No. 1557. 
Gambacorta, L., and C. Rosi (2007), "Modelling Bank Lending in the Euro Area: A Non-linear Approach,” Banca d'Italia Working Paper, No. 650.

Georgiadis, G. (2015), "Determinants of Global Spillovers from U.S. Monetary Policy," Journal of International Money and Finance (forthcoming).

Hakkio, C. S., and G. A. Kahn (2014), "Evaluating Monetary Policy at the Zero Lower Bound," Federal Reserve Bank of Kansas City Economic Review, $2^{\text {nd }}$ quarter 2014, pp. 5-32.

Krippner, L. (2014), "Documentation for United States Measures of Monetary Policy," Reserve Bank of New Zealand.

Lavigne, R., S. Sarker, and G. Vasishtha (2014), "Spillover Effects of Quantitative Easing on Emerging Market Economies," Bank of Canada Review, autumn 2014, pp. 23-33.

Lombardi, M. J., and F. Zhu (2014), "A Shadow Policy Rate to Calibrate U.S. Monetary Policy at the Zero Lower Bound," BIS Working Paper, No. 452.

MacDonald, M. (2015), "International Capital Market Frictions and Spillovers from Quantitative Easing," Queen's Economic Department Working Paper, No. 1346.

Miyajima, K., M. S. Mohanty, and J. Yetman (2014), "Spillovers of U.S. Unconventional Monetary Policy to Asia: The Role of Long-term Interest Rates,” BIS Working Paper, No. 478.

Rogers, J. H., C. Scotti, and J. H. Wright (2014), "Evaluating Asset-market Effects of Unconventional Monetary Policy: A Cross-country Comparison," International Finance Discussion Papers, No. 2014-1101, Washington, D.C.: Board of Governors of the Federal Reserve System.

Tenreyro, S., and G. Thwaites (2015), "Pushing on a String: U.S. Monetary Policy is Less Powerful in Recessions," CEP Discussion Papers, No. 1218, Centre for Economic Performance, LSE.

Tillmann, P. (2015), "Unconventional Monetary Policy Shocks and the Response of Emerging Markets," Journal of International Money and Finance (forthcoming). 
Uhlig, H. (2005), "What are the Effects of Monetary Policy on Output? Results from an Agnostic Identification Procedure," Journal of Monetary Economics, Vol. 52, pp. 381-419.

Wu, J. C., and F. D. Xia (2014), "Measuring the Macroeconomic Impact of Monetary Policy at the Zero Lower Bound," NBER Working Paper, No. 20117.

Wu, T., and M. Cavallo (2012), "Measuring Oil-price Shocks Using Market-based Information," IMF Working Paper, WP/12/19. 


\section{Appendix: Alternative Shadow Rate}

Figure (A1) presents the cumulated impulse responses based on the Krippner shadow rate. Surprisingly, for stock prices the spillovers in the first sample are larger than those for the second, while for the other two variables the comparison of both sample periods is less clear. As argued by Hakkio and Kahn (2014), the Krippner-rate suffers from two weaknesses: it is too volatile to be an indicator of gradual policy and it deviates from the actual Federal Funds rate even before the zero lower bound is reached. Therefore, we focus on the Wu-Xia shadow rate and derive the shock component of it with the help of an auxiliary VAR. The investigations into the asymmetry and the explanatory power of fundamentals presented in the main part of the paper are carried out for the shock component of the policy rate only.

Figure A.1: Cumulated Impulse Responses of Financial Variables to the $0.25 \%$ p Increase in the Krippner U.S. Shadow Rate
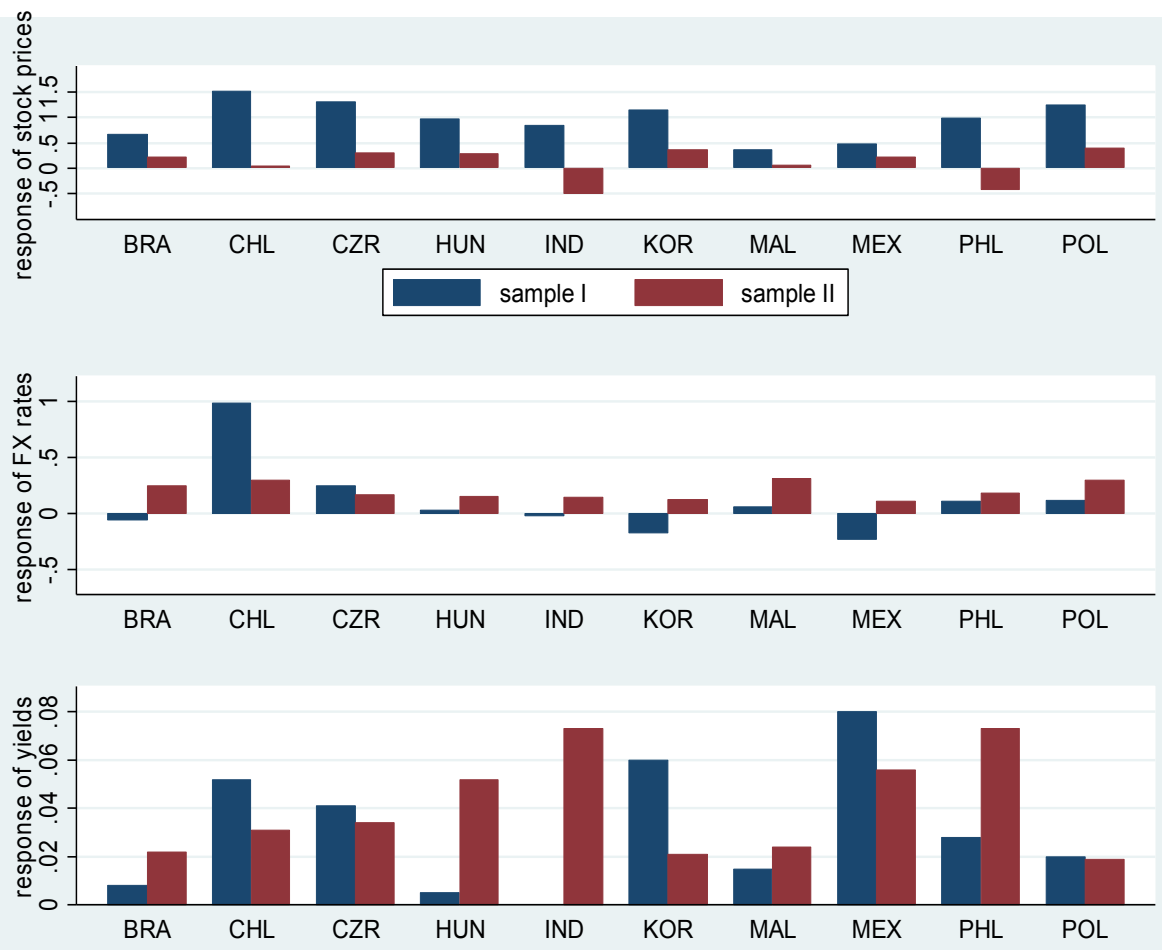


\section{$<$ Abstract in Korean $>$}

\section{미국 통화정책 충격이 신흥국 금융시장에 미치는 파급효과}

\section{김근영*, 박하일**, Peter Tillmann***}

본 연구는 미국 통화정책 충격이 신흥국 금융시장에 미치는 영향을 양적 완화와 전통적 금리정책 효과의 비교, 양적 완화의 확대·축소 시 파급효과의 비대칭성, 그리고 파급정도에 있어 경제펀더멘털의 역할 등에 초점을 두고 실증 분석하였다. VAR-X 모형을 이용하여 10 개 신흥국의 주별 환율, 주가 및 금리자료를 토대로 추정한 결과 다음의 세 가지 주요 특징을 발견하였다. (i) 미국 통화정책 충격이 신흥국 금융시장에 미치는 파급효과는 국별, 금융 변수별로 글로벌 금융위기 전후에 차별화된 양상을 보였다. 즉 다수 국가에서 전통적, 비전통적 통화정책 수행기간에 주식시장 반응의 부호가 반대로 나타나거나, 단기금리에 미치는 영향의 유의성에 큰 차이를 보였다. (ii) 미국 통화정책 충격을 '긴축' 및 '완화' 충격으로 구분하여 살펴 본 결과, 글로벌 금융위기 이후 양적 완화 혹은 양적 완화 축소 정책의 파급효과에 비대칭성이 관찰되었다. 즉 양적 완화 충격보다 양적 완화 축소 충격이 신흥국의 주식 및 외환시장에 더 큰 영향을 초래한 것으로 나타났다. (iii) 거시펀더멘털이 취약할수록 대체로 미국 통화정책 충격에 대한 반응도가 커지는 경향이 있었다.

따라서 신흥국은 선진국 통화정책 충격에 따른 금융시장 변동성 확대의 부정적 여파가 경제전반에 확산되지 않도록, 각 국가별로 취약한 부문을 중심으로 경제의 펀더멘털을 개선해 나가면서 거시건전성정책 등 효율적인 정책대응체계를 강화해 나가는 것이 바람직하다.

핵심주제어: 통화정책, 양적 완화, 파급경로, VAR-X, 비대칭성

JEL Classification: E58, F32, F42

\footnotetext{
* 한국은행 경제연구원

** 경희대학교

*** 독일 Giessen대학교
}

이 연구내용은 집필자의 개인의견이며 한국은행의 공식견해와는 무관합니다. 따라서 본 논문의 내용을 보도하거나 인용할 경우에는 집필자명을 반드시 명시하여 주시기 바랍니다. 